\title{
ASAS PEMISAHAN HORIZONTAL DALAM KEPEMILIKAN HAK ATAS TANAH DAN BANGUNAN SATUAN RUMAH SUSUN BAGI MASYARAKAT BERPENGHASILAN RENDAH (MBR)
}

\author{
Betty Rubiati, Yani Pujiwati, Mulyani Djakaria \\ Staf Pengajar Fakultas Hukum Unpad \\ Email:rubiatibetty@yahoo.co.id
}

\begin{abstract}
ABSTRAKPembangunan perumahan dan permukiman merupakan kebijakan untuk memenuhi kebutuhan dasar manusia.Dalam rangka peningkatan daya guna dan hasil guna tanah serta mengefektifkan penggunaan tanah terutama di daerah-daerah berpenduduk padat dan di kota-kota besar yang tanahnya sudah terbatas perlu diarahkan pembangunan perumahan dan permukiman dalam bentuk dan sistem Rumah Susun. Kepemilikan rumah susun yang ada saat ini menyatukan satuan rumah susun dengan hak atas tanahnya yang harganya semakin tinggi sehingga sulit dijangkau oleh Masyarakat Berpenghasilan Rendah.Metode yang digunakan dalam penelitian ini adalah deskriptif analitis dengan pendekatan yuridis normatif. Data yang diperoleh dari penelitian kepustakaan dan pelitian lapangan dianalisis secara normatif kualitatifKepemilikan satuan rumah susun saat ini sudah menerapkan asas pemisahan horisontal, hal ini terlihat bahwa rumah susun dapat dibangun diatas tanah milik orang lain, namun Sertifikat Hak Milik Atas Satuan Rumah Susun yang menyatukan kepemilikan satuan rumah susun dengan tanah bersama menunjukkan masih dipengaruhi asas perlekatan. Dalam kepemilikan rumah susun melalui pemanfaatan barang milik negara/daerah berupa tanah dan pendayagunaan tanah wakaf dengan cara sewa dengan bukti kepemilikan berupa Sertifikat Kepemilikan Bangunan Gedung Satuan rumah susun menunjukan penerapan asas pemisahan horisontal secara konsisten. Berbagai upaya telah dilakukan oleh Pemerintah untuk memenuhi kebutuhan rumah bagi MBR, namun belum bisa terlaksana dengan baik, hal ini disebabkan karena pemilikan rumah susun bagi Masyarakat Berpenghasilan Rendah masih dikaitkan dengan hak atas tanah yang harganya semakin meningkat. Pemilikan rumah susun yang memisahkan dengan hak atas tanahnya diharapkan dapat memenuhi kebutuhan rumah bagi Masyarakat Berpenghasilan Rendah, namun sampai saat ini belum dapat dilaksanakan, selain belum ada peraturan pelaksanaan UU Rumah Susun juga belum ada instansi yang dapat melakukan pendaftarannya.
\end{abstract}

Kata Kunci : Rumah Susun, Masyarakat Berpenghasilan Rendah, SKBG Sarusun

\section{THE PRINCIPLE OF HORIZONTAL SEPARATION IN THE OWNERSHIP OF RIGHT OVER LAND AND PROPERTY OF APARTMENT UNIT FOR PEOPLE WITH LOW SALARY}

ABSTRACT The development of housing and shelter is a policy to fulfill the basic need of human being. In order to increase the efficiency and the effectiveness of land and optimize the use of land, especially in the areas with highly-densed population and in big cities with limited vacant lands, it is necessary to direct the orientation of housing development towards the apartment system. The current regulation on apartment ownership unifies the apartment units and the rights over the land, with such a high price that is hard to afford by People with Low Salary. The method used in this study is a analytical descriptive with a normative juridical approach. The data obtained from library research and field research juridical qualitatively analyzed The result shows that the principle of horizontal separation had been applied within the first year of the ownership of apartment unit. This is proven by the establishment of apartment on people's land, either of the building rights or the use rights. However, proprietary certificate of the apartment unifying the ownership of apartment unit and common land is still influenced by the principle of attachment. The ownership of apartment through the utilization of government property and waqf land by way of rental contract with the certificate of ownership of Strata Title unit as the proof of ownership shows the consistency of the application of the principle of horizontal separation. Despite the various efforts of the government to fulfill the need for housing of the people with low salary, the program hasn't been well performed. The rate of backlog of housing remains high, reaching up to 15 million units. This is because the ownership of apartment for people with low salary is still related to the rights over land, the price of which is getting higher. The ownership of apartment unit with the separation of the rights over the land is expected to help with the fulfilment of need of people with low salary although it hasn't been completely carried out. Even government body has not started the registration because the regulation of apartment law performance hasn't been established.

Keywords : Apartment, People with Low Salary, certificate of ownership of Strata Title unit

\section{PENDAHULUAN}

Pembangunan nasional di Indonesia bertujuan untuk menciptakan masyarakat yang adil dan makmur berdasarkan Pancasila dan Undang Undang Dasar Negara Republik Indonesia Tahun 1945 ( UUD 1945). Pasal 28H ayat (1) UUD 1945 menegaskan bahwa setiap orang berhak hidup sejahtera lahir dan bathin, bertempat tinggal, dan mendapatkan lingkungan hidup yang baik dan sehat. Oleh karena itu Negara bertanggungjawab untuk menjamin pemenuhan hak akan tempat tinggal dalam bentuk rumah yang layak dan terjangkau. ${ }^{1}$

Pembangunan perumahan dan permukiman merupakan kebijakan untuk memenuhi kebutuhan

\footnotetext{
Penjelasan Umum Undang-undang RI Nomor 20 Tahun 2011 tentang Rumah Susun
} 
dasar manusia.Negara bertanggungjawab dalam menyediakan dan memberikan kemudahan perolehan rumah bagi masyarakat melalui penyelenggaraan perumahan dan kawasan permukiman.

Dalam rangka peningkatan daya guna dan hasil guna tanah serta mengefektifkan penggunaan tanah terutama di daerah-daerah berpenduduk padat dan di kota-kota besar yang tanahnya sudah terbatas perlu diarahkan pembangunan perumahan dan permukiman dalam bentuk dan sistem Rumah Susun.

Dalam rangka pelaksanaan visi dan misi Presiden pada Pemilu Tahun 2004, Pemerintah telah mengeluarkan Perpres Nomor 7 Tahun 2005 tentang Rencana Pembangunan Jangka Menengah Nasional 2004-2009, di mana salah satu permasalahan dan Agenda pentingnya adalah upaya percepatan pembangunan infrastruktur, termasuk di dalamnya masalah pembangunan perumahan dan permukiman guna memenuhi kebutuhan masyarakat akan papan yang layak dalam lingkungan yang sehat. Termasuk di dalam upaya ini adalah pembangunan Rumah Susun Sederhana Sewa (Rusunawa) sebanyak 60 ribu unit dan Rumah Susun Sederhana Milik (Rusunami) sebanyak 25 ribu unit bagi kebutuhan masyarakat berpenghasilan menengah ke bawah dengan tingkat penghasilan di bawah Rp. 4,5 juta per bulan melalui peran serta swasta atau kerjasama Pemerintah dan Swasta ( Public Private Partnership ).

Guna menindaklanjuti Perpres Nomor 7 Tahun 2005 tersebut, Pemerintah telah menerbitkan Keppres Nomor 22 Tahun 2006 tentang Percepatan Pembangunan Rumah Susun di Kawasan Perkotaan, khususnya pembangunan Rusunawa dan Rusunami sebanyak 1000 Tower Apartemen Murah Pro Rakyat ( Pro Populis ) sampai dengan Tahun 2011 dengan mendapatkan bantuan subsidi dan insentif dari Pemerintah/Pemda. Pembangunan Rusuna ini di prioritaskan di kawasan perkotaan dengan jumlah penduduknya di atas 1,5 juta jiwa. Kebijakan percepatan pembangunan Perumahan dan Permukiman serta Rumah Susun tersebut sangat bijaksana, mengingat kebutuhan perumahan yang layak huni tersebut semakin hari semakin meningkat. Menurut AP. Parlindungan, ${ }^{2}$ pembangunan Rumah Susun, terutama di wilayah perkotaan, merupakan suatu kemutlakan sebagai akibat terbatasnya tanah untuk perumahan tersebut dan permintaan akan papan semakin tinggi.

Guna memenuhi kebutuhan penting masyarakat perkotaan, dibentuklah Undang-undang Nomor 16 Tahun 1985 tentang Rumah Susun. Menurut Pasal 3 UU Rusun ini, tujuan pembangunan Rumah Susun dijelaskan sebagai berikut:

1. a. Memenuhi kebutuhan perumahan yang layak bagi rakyat, terutama

golongan masyarakat berpenghasilan rendah, yang menjamin

kepastian hukum dalam pemanfaatannya.

2 AP. Parlindungan, Komentar Atas Undang-undang Perumahan dan Per mukiman dan Undang-undang Rumah Susun, Bandung : Mandar Maju, 2001, hlm. 91 b. Meningkatkan daya guna dan hasil guna tanah di daerah perkotaan dengan memperhatikan kelestarian sumber daya alam dan menciptakan lingkungan permukiman yang lengkap, serasi dan seimbang.

2. Memenuhi kebutuhan untuk kepentingan lainnya yang berguna bagi kehidupan masyarakat, dengan tetap mengutamakan ketentuan ayat (1) huruf a.

Perkembangan penduduk yang semakin pesat terutama di daerah perkotaan tidak seimbang dengan kebutuhan akan lahan tanah yang ada yang tidak dapat bertambah luasnya. Hal ini menyebabkan harga tanah semakin tinggi. ${ }^{3}$ Dengan menyatukan kepemilikan satuan rumah susun beserta tanahnya, menyebabkan harga jual rumah susun termasuk hak atas tanahnya menjadi tinggi dan tidak terjangkau oleh masyarakat berpenghasilan rendah

Dalam UU No. 20 Tahun 2011 tentang Rumah Susun, dijelaskan bahwa penyelenggaraan rumah susun bertujuan untuk menjamin terwujudnya rumah susun yang layak huni dan terjangkau, meningkatkan efisiensi dan efektivitas pemanfaatan ruang. UU ini juga menunjukkan keberpihakan Negara dalam memenuhi kebutuhan tempat tinggal yang terjangkau bagi MBR serta partisipasi masyarakat dalam penyelenggaraan rumah. ${ }^{4}$, yaitu adanya jaminan kepastian kepemilikan dan kepenghunian atas sarusun bagi MBR yang memungkinkan memiliki sarusun tanpa hak atas tanahnya atau terlepas dari hak atas tanahnya melalui pemanfaatan barang milik Negara/ daerah berupa tanah dan pendayagunaan tanah wakaf, dengan bukti kepemilikan berupa Sertipikat Kepemilikan Bangunan Gedung Sarusun ( SKBG Sarusun )

Berdasarkan latar belakang yang telah diuraikan di atas, permasalahan akan dibatasi sebagai berikut :

1. Apakah kepemilikan satuan rumah susun di Indonesia sudah menggunakan asas pemisahan horizontal atas tanah dan bangunan?

2. Apakah penggunaan asas pemisahan horizontal dalam kepemilikan tanah dan bangunan satuan rumah susun dapat memenuhi kebutuhan rumah bagi MBR ?

3. Bagaimanakah pendaftaran kepemilikan bangunan gedung satuan rumah susun bagi MBR ?

\section{METODE}

Penelitian ini bersifat deskriptif analitis, yaitu membuat pencandraan sistematis, faktual dan akurat mengenai fakta-fakta. ${ }^{5}$ Juga dimaksudkan untuk memberikan data seteliti mungkin tentang manusia dan gejala lainnya. ${ }^{6}$

Metode pendekatan yang digunakan dalam penelitian ini adalah metode pendekatan yuridis normatif, yaitu menelusuri, mengkaji dan meneliti data sekunder yang berkaitan dengan materi

\footnotetext{
3 Djuhaendah Hasan, Lembaga Jaminan Kebendaan Bagi Tanah Dan Ben da Lain yang Melekat Pada Tanah Dalam Konsepsi Penerapan Asas Pemisahan Horisontal, Bandung : PT. Citra Aditya Bakti, 1996, hlm. 333 4 Penjelasan Umum Undang-undang Nomor 20 Tahun 2011 tentang Rumah Susun.

5 Sumadi, Metode Penelitian, CV Rajawali, Jakarta, 1988, hlm. 19.

6 Soerjono Soekanto,Penelitian Hukum, UI Press, Jakarta, 1990, hlm. 10.
} 
penelitian . Digunakannya pendekatan yuridis dengan pertimbangan masalah yang diteliti berkisar pada keterkaitan suatu peraturan dengan peraturan lainnya. Data yang telah dikumpulkan baik data sekunder maupun data primer, keseluruhannya akan dianalisis berdasarkan analisis Normatif kualitatif dan hasilnya akan dipaparkan secara deskripsi, sehingga diperoleh gambaran yang menyeluruh tentang permasalahanpermasalahan yang diteliti.

\section{HASIL DAN PEMBAHASAN}

Penggunaan Asas Pemisahan Horozontal Dalam Kepemilikan Tanah Dan Bangunan Satuan Rumah Susun Di Indonesia

Salah satu aspek yang penting di dalam hukum tanah adalah tentang hubungan hukum antara tanah dengan benda lain yang melekat padanya. Kepastian hukum akan kedudukan hukum dari benda yang melekat pada tanah itu sangat penting karena hal ini mempunyai pengaruh yang luas terhadap segala hubungan hukum yang menyangkut tanah dan benda yang melekat padanya ${ }^{7}$.

Di dalam hukum tanah dikenal ada 2 (dua) asas yang satu sama lain bertentangan yaitu yang dikenal dengan asas pelekatan Vertikal (verticale accessie beginsel) dan asas pemisahan horisontal (horizontale scheiding beginsel) ${ }^{8}$.

Sejak berlakunya KUH Perdata kedua asas ini diterapkan secara berdampingan sesuai dengan tata hukum yang berlaku dewasa itu (masih dualistis). Sejak berlakunya UUPA maka ketentuan Buku II KUH Perdata sepanjang mengenai bumi, air serta kekayaan di dalamnya telah dicabut, kecuali tentang hipotik.

Asas pelekatan vertikal yaitu asas yang mendasarkan pemilikan tanah dan segala benda yang melekat padanya sebagai suatu kesatuan yang tertancap menjadi satu' . Dalam hukum tanah Negaranegara yang menggunakan apa yang disebut Asas Accessie atau Asas pelekatan, bangunan dan tanaman yang ada di atas dan merupakan satu kesatuan dengan tanah, merupakan bagian dari tanah yang bersangkutan. Hak atas tanah dengan sendirinya, karena hukum, meliputi juga pemilikan bangunan dan tanaman yang ada di atas tanah yang dihaki. Kecuali kalau ada kesepakatan lain dengan pihak yang membangun atau menanamnya (Pasal 500 dan 571 KUH Perdata) ${ }^{10}$. Perbuatan hukum mengenai tanah dengan sendirinya meliputi tanaman dan bangunan yang ada di atasnya.Umumnya bangunan dan tanaman yang ada di atas tanah adalah milik yang empunya tanah ${ }^{11}$.

Dalam hukum Indonesia dimungkinkan pemilikan secara pribadi bagian-bagian bangunan, karena hukum Indonesia menggunakan asas pemisahan horizontal, yaitu_asas hukum adat yang merupakan

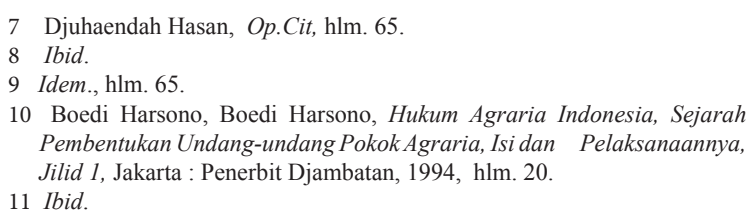

dasar Hukum Tanah Nasional. ${ }^{12}$ Berdasarkan asas pemisahan horizontal pemilikan atas tanah dan benda-benda yang berada di atas tanah itu adalah terpisah. Pemilikan atas tanah terlepas dari bendabenda yang ada di atas tanah, sehingga pemilik hak atas tanah dan pemilik atas bangunan yang berada di atasnya dapat berbeda. ${ }^{13}$

Asas pemisahan horizontal hak-hak atas tanah yang merupakan sifat asli hak-hak dalam hukum adat, tetap dipertahankan tetapi disesuaikan dengan kenyataan kebutuhan masyarakat masa kini.Hak atas tanah tidak meliputi pemilikan atas bangunan yang ada di atasnya. Bangunan, tanaman dan bendabenda lain yang ada di atas suatu bidang tanah adalah milik pihak yang membangun atau yang menanam, baik pihak itu pemegang hak atas tanahnya sendiri atau bukan, kecuali kalau ada perjanjian sebaliknya. Maka perbuatan hukum mengenai tanah tidak dengan sendirinya meliputi bangunan, tanaman dan/atau benda-benda lain yang ada di atasnya, kalau hal itu tidak secara tegas dinyatakan. ${ }^{14}$

Namun demikian penerapan asas-asas hukum adat tidaklah mutlak melainkan selalu memperhatikan dan disesuaikan dengan perkembangan kenyataan dan kebutuhan dalam masyarakat yang dihadapinya.

Selanjutnya dapat dilihat penerapan asas pemisahan horisontal dalam ketentuan UUPA yang terlihat dengan jelas pada ketentuan dalam Pasal 35 tentang HGB, HGU Pasal 28, Pasal 41 tentang hak pakai dan Pasal 44 tentang hak sewa untuk bangunan. Di dalam ketentuan itu seseorang dapat mendirikan bangunan di atas tanah milik orang lain, jadi pemilikan atas bangunan berbeda dengan pemilikan atas tanahnya ${ }^{15}$. Untuk itu Hak Guna Bangunan diartikan sebagai hak untuk mendirikan bangunan di atas tanah orang lain, di atas tanah hak milik atau di atas tanah Negara.

Menuntut Pasal 17 dan 18 UU Rumah Susun, Rumah Susun dapat diangun di atas tanah :

a. Hak Milik;

b. Hak Guna Bangunan atau Hak Pakai atas tanah Negara,

c. Hak Guna Bangunan atau Hak Pakai di atas Hak Pengelolaan;

d. Barang milik Negara/daerah berupa tanah

e. Tanah Wakaf.

Dari ketentuan Pasal 17 dan 18 UU Rumah Susun tersebut terlihat bahwa Rumah Susun dapat dibangun diatas tanah milik orang lain, hal ini menunjukkan bahwa UU Rumah Susun menerapkan asas pemisahan horisontal. Akan tetapi apabila dilihat dari pengertian Rumah Susun menurut Penjelasan Pasal 22 ayat (2) UU Perumahan dan Kawasan Permukiman jo Pasal 1 ayat (1) Undang-undang Nomor 20 Tahun 2011 tentang Rumah Susun, menyebutkan :

"Rumah Susun adalah bangunan gedung bertingkat 12 Ibid

13 Imam Sudiyat, Hukum Adat Sketsa Asas, Yogjakarta : Liberty, 1981, hlm. 54

14 Boedi Harsono, Menuju Penyempurnaan Hukum Tanah Nasional Dalam Hubungannya Dengan TAP

MPR RI IX/MPR/2001, Jakarta : Penerbit Universitas Trisakti, 2003, hlm.73 15 Ibid, hlm. 88 . 
yang dibangun dalam satu lingkungan yang terbagi dalam bagian-bagian yang distrukturkan secara fungsional dalam arah horizontal maupun vertical dan merupakan satuan-satuan yang masing-masing dapat dimiliki dan digunakan secara terpisah, terutama untuk tempat hunian, yang dilengkapi dengan bagian bersama, benda bersama dan tanah bersama."

Selanjutnya, pemisahan rumah susun wajib dituangkan dalam bentuk gambar dan uraian. Gambar dan uraian ini yang menjadi dasar untuk menetapkan Nilai Pernandingan Proporsional (NPP) dalam tanda bukti kepemilikan sarusun, yaitu : Sertipikat Hak Milik Sarusun (SHM Sarusun) utuk sarusun yang berdiri di atas tanah Hak Milik, Hak Guna Bangunan atau Hak Pakai di atas tanah Negara, serta Hak Guna Bangunan atau Hak Pakai di atas tanah Hak Pengelolaan. Sedangkan Sertipikat Kepemilikan Bangunan Gedung Sarusun ( SKBG Sarusun ) untuk sarusun yang dibangun di atas barang milik Negara/daerah berupa tanah atau tanah wakaf melalui sewa.

Sertipikat Hak Milik atas Satuan Rumah Susun ini yang menunjukkan adanya pengaruh dari asas perlekatan, karena kepemilikan satuan rumah susun termasuk didalamnya kepemilikan tanah bersama. SHM Sarusun dikeluarkan oleh Kantor Pertanahan Kabupaten/Kota dimana letak tanah yang dibangun Rumah Susun.

Berdasarkan uraian di atas, maka SKBG Sarusun merupakan perwujudan dari asas pemisahan horisontal yang dianut dalam hukum adat dan hukum adat menjadi dasar dari hukum pertanahan Indonesia. ${ }^{16}$ Kedudukan tanah wakaf yang disewa untuk dipergunakan pembangunan rumah susun menganut asas pemisahan horisontal, sehingga tanah wakaf tidak berubah fungsinya, masih sebagai tanah wakaf. Demikian pula halnya dengan barang milik negara/daerah berupa tanah yang di sewakan untuk dibangun rumah susun menggunakan asas pemisahan horisontal, sehingga negara/daerah tidak perlu melepaskan aset miliknya berupa tanah tersebut.

Pemanfaatan barang milik Negara melalui sewa diatur dalam Pasal 21 dan 22 PP No. 6 Tahun 2006. Pasal 22 menyebutkan bahwa barang milik Negara/ daerah dapat disewakan kepada pihak lain sepanjang menguntungkan Negara/daerah dengan jangka waktu paling lama 5 tahun dan dapat diperpanjang. Karena menurut Kepala Pusat Penelitian dan Pengembangan Badan Pertanahan Nasional (BPN), Maharani bentuk pendayagunaan Tanah BMN/D menyentuh peraturan Undang-Undang sektor lainnya, yaitu UndangUndang Perbendaharaan Negara maka pendayagunaan/ pemanfaatan tanah dimaksud bagi pembangunan untuk Rumah Susun harus dilakukan sesuai ketentuan yang mengatur tanah BMN/D hal tersebut dinyatakan / diatur pula dalam UU Rumah Susun, bahwa pemanfaatan tanah BMN/BMD harus Sesuai dengan ketentuan Peraturan Perundang-undangan yang berlaku. ${ }^{17}$

16 Yani Pujiwati, "Kedudukan Tanah Wakaf Dihubungkan Dengan Sertipikat Kepemilikan Bangunan Gedung Satuan Rumah Susun, LaporanPenelitian DIPA Fakultas Hukum Unpad 2013, hlm.34
Demikian pula mengenai pendayagunaan tanah wakaf untuk pembangunan rumah susun dengan cara sewa atau kerja sama pemanfaatan dilakukan sesuai dengan ikrar wakaf dan dilakukan sesuai dengan prinsip syariah.

\section{Pemenuhan Kebutuhan Rumah Bagi MBR melalui Penggunaan Asas Pemisahan Horizontal}

Pasal 28H ayat (1) UUD 1945 menegaskan bahwa setiap orang berhak hidup sejahtera lahir dan bathin, bertempat tinggal, dan mendapatkan lingkungan hidup yang baik dan sehat., Negara bertanggungjawab untuk menjamin pemenuhan hak akan tempat tinggal dalam bentuk rumah yang layak dan terjangkau. ${ }^{18}$

Dalam Undang-undang No. 20 Tahun 2011 tentang Rumah Susun dijelaskan bahwa penyelenggaraan rumah susun bertujuan untuk menjamin terwujudnya rumah susun yang layak huni dan terjangkau, meningkatkan efisiensi dan efektivitas pemanfaatan ruang. UU ini juga menunjukkan keberpihakan Negara dalam memenuhi kebutuhan tempat tinggal yang terjangkau bagi Masyarakat Berpenghasilan Renah (MBR) serta partisipasi masyarakat dalam penyelenggaraan rumah. ${ }^{19}$

Dalam UU Rumah Susun ini mengembangkan pembangunan rumah susun melalui pemanfaatan barang milik Negara/daerah berupa tanah dengan sewa yang berjangka waktu 60 tahun, dengan bukti kepemilikan berupa Sertipikat Kepemilikan Bangunan Gedung Sarusun ( SKBG Sarusun ).

Dari uraian di atas terlihat bahwa kepemilikan satuan rumah susun yang diperuntukan bagi Masyarakat Berpenghasilan Rendah (MBR) yang lebih dikenal dengan Rumah Susun Sederhana Milik (Rusunami) termasuk didalamnya kepemilikan atas tanah bersama.Hal ini yang menyebabkan harga rumah susun yang dibangun di atas tanah hak milik, hak guna bangunan dan hak pakai cukup mahal yang sulit dijangkau oleh MBR.

Berbagai upaya dan berbagai kebijakan sudah dikeluarkan oleh pemerintah untuk memenuhi kebutuhan rumah bagi MBR.Sejak dikeluarkannya Keputusan Menteri Negara Perumahan dan Permukiman No. 10/KPTS/M/1999 tentang Kebijakan dan Strategi Pembangunan Rumah Susun. Saat itu pemerintah mendorong pembangunan perumahan di kota-kota besar dan metropolitan serta kawasan yang mempunyai kendala secara fisik

dalam perluasan kotanya, untuk dilaksanakan ke arah vertikal dalam bentuk rumah susun. ${ }^{20}$

Selanjutnya pemerintah mengeluarkan Peraturan Menteri Dalam Negeri No. 74 Tahun 2007 tentang Pedoman Pemberian Kemudahan Perizinan dan Insentif Dalam Pembangunan Rumah Susun Sederhana Di Kawasan Perkotaan. Dalam Pasal

17 Betty Rubiati, "Kepemilikan Satuan Rumah Susun Yang Dibangun Melalui Pemanfaatan Barang Milik Negara/Daerah Berupa Tanah", Laporan Penelitian DIPA Fakultas Hukum Unpad Tahun 2013, hlm.35

18 Penjelasan Umum Undang-undang RI Nomor 20 Tahun 2011 tentang Rumah Susun

19 Penjelasan Umum Undang-undang Nomor 20 Tahun 2011 tentang Rumah Susun.

20 Y. Fitriadi, "Kapan Lagi Ada Rusun Murah", Harian Umum Pikiran Rakyat, 6 April 2013, hlm. 24 
3 Permendagri ini disebutkan untuk mewujudkan percepatan pembangunan rumah susun sederhana, Pemerintah Daerah harus melakukan :

a. Pembentukan Tim Koordinasi Percepatan Pembangunan Rusuna Tingkat Daerah,

b. Keharusan menyusun Perda yang mendorong percepatan pembangunan rusuna,

c. Penentuan dan penetapan lokasi-lokasi yang memenuhi kriteria yang diperuntukan bagi pembangunan rusuna,

d. Harus adanya kemudahan perizinan dan insentif kepada pengembang untuk membangun rusuna.

Sedemikian lengkapnya pengaturan yang dimuat dalam Permendagri No. 74 Tahun 2007, namun sudah tujuh tahun berlalu masih belum efektif. Paling tidak di Jawa Barat tidak ada Tim Percepatan yang diketuai Gubernur, apalagi dalam hal kemudahan insentif bagi pengembang rusuna. ${ }^{21}$

Dari sisi MBR, pemerintah sudah mengeluarkan Permenpera No. 03/PERMEN/M/2007 tentang Pengadaan Perumahan dan Permukiman Dengan Dukungan Fasilitas Subsidi Perumahan Melalui KPR Bersubsidi yang bertujuan untuk menjangkau lebih banyak kelompok sasaran MBR yang mempunyai penghasilan paling banyak Rp. 2,5 juta perbulan. Kemudian diganti dengan Permenpera No. 4 Tahun 2012 tentang Pengadaan Perumahan Melalui Kredit/PembiayaanPemilikan Rumah Sejahtera Dengan Dukungan Fasilitas Likuiditas Pembiayaan Perumahan (FLPP), yaitu dukungan fasilitas likuiditas pembiayaan perumahan kepada MBR yang pengelolaannya dilaksanakan oleh Kemenpera. Dengan kelompok sasaran MBR Rumah Sejahtera Tapak adalah penghasilan tetap maupun tidak tetap paling banyak Rp. 3,5 juta perbulan, dan MBR Rumah Sejahtera Susun dengan penghasilan paling banyak Rp. 5,5 juta perbulan.

Selanjutnya berdasarkan Peraturan Menteri Keuangan No. 25 Tahun 2011, saat ini rumah MBR dibebaskan dari PPN ( Pajak Pertambahan Nilai) $10 \%$. Hal ini membuat harha jual rumah bagi MBR bisa lebih ditekan.Apalagi PPh (Pajak Penghasilan) Final untuk pengembang rumah MBR juga mendapat pengurangan dari $5 \%$ menjadi $1 \%$.

Berbagai kebijakan yang dilakukan pemerintah ini ditujukan untuk mengurangi angkabacklog ( defisit rumah dibandingkan dengan jumlah keluarga ) yang terus meningkat dan pada Tahun 2013 sudah mencapai 15 juta unit, ${ }^{22}$ dan dikhawatirkan akan terus meningkat di Tahun 2014 ini.

Untuk mendorong Pemerintah Daerah dalam percepatan pembangunan rumah susun bagi MBR diperlukan peran serta Menteri Dalam Negeri. Berdasarkan hasil penelitian, saat ini sudah mulai dibuat Rancangan Peraturan Menteri Dalam Negeri Tentang Pedoman Optimalisasi Pemanfaatan Tanah Kawasan Perkotaan Untuk Pembangunan Perumahan Dan Kawasan Permukiman Bagi Masyarakat

\footnotetext{
21 Y. Fitriadi, "Menjamin Hak Bermukim MBR Di Perkotaan", Harian Umum Pikiran Rakyat, 24 Mei 2014, hlm.26 22 Ibid
}

Berpenghasilan Rendah, dengan tujuan :

a. Meningkatkan kapasitas kelembagaan pemerintah daerah dalam mendukung percepatan pembangunan perumahan dan kawasan permukiman di kawasan perkotaan;

b. Mendorong percepatan ketersediaan tanah untuk perumahan dan permukiman bagi MBR di kawasan perkotaan;

c. Mendorong tersedianya rumah susun umum yang layak dan terjangkau bagi MBR di kawasan perkotaan;

d. Mewujudkan kawasan perkotaan berwawasan lingkungan dan tanpa kumuh.

Khusus di Kota Bandung, dalam upaya memenuhi kebutuhan rumah bagi MBR, sesuai dengan Rencana Program Perumahan dan Permukiman Kota Bandung, dalam Rencana Jangka Panjang salah satunya adalah Pembangunan Apartemen Rakyat di Wilayah Antapani. ${ }^{23}$ Apartemen ini akan dibangun diatas tanah Pemda Kota Bandung dengan status Hak Pengelolaan. Akan tetapi tanah tersebut dibangun Rumah Susun dengan status Hak Guna Bangunan di atas Hak Pengelolaan.

Rencana pembangunan Apartemen Rakyat masih dalam proses studi kelayakan berkaitan dengan perizinan. $^{24}$

\section{Pendaftaran Kepemilikan Bangunan Gedung Satuan Rumah Susun Bagi Masyarakat Berpenghasilan Rendah}

Menurut Pasal 5 PP Pendaftaran Tanah disebutkan bahwa pendaftaran tanah diselenggarakan oleh Badan Pertanahan Nasional, yang dalam pelaksanaannya dilakukan oleh Kepala Kantor pertanahan Kabupaten/ Kota dimana letak tanah.

Sementara itu yang menjadi objek pendaftaran tanah menurut Pasal 9 PP Pendaftaran Tanah adalah :

1. Bidang-bidang tanah yang dipunyai dengan hak milik, hak guna usaha, hak guna bangunan dan hak pakai;

2. Tanah hak pengelolaan;

3. Tanah wakaf;

4. Hak milik atas satuan rumah susun

5. Hak tanggungan;

6. Tanah Negara.

Menurut Pasal 47 UU Rumah Susun, sebagai tanda bukti kepemilikan atas sarusun di atas tanah hak milik, hak guna bangunan atau hak pakai di atas tanah Negara, hak guna bangunan atau hak pakai di atas tanah hak pengelolaan diterbitkan SHM Sarusun yang diterbitkan oleh Kantor Pertanahan Kabupaten/ Kota. Sedangkan sebagai tanda bukti kepemilikan atas sarusun di atas barang milik Negara/daerah berupa tanah dan tanah wakaf dengan cara sewa, diterbitkan SKBG Sarusun oleh Instansi Teknis

23 Dodit Ardian Pancapana, (Kabid Perumahan Distarcip Kota Bandung) "Pembangunan Peradaban, Membangun Tanpa Menggusur" disampaikan pada Focus Group Discussion Penerapan Asas Pemisahan Dalam Kepemilikan Tanah Dan Bangunan Satuan Rumah Susun Dalam Upaya Memenuhi Rumah Bagi MBR, Fakultas Hukum Universitas Padjadjaran,Bandung 08 September 2014, hlm. 1

24 Wawancara dengan Ayu Nilamsari, staf Bidang Perumahan, Distarcip Kota Bandung, 17 September 2014 
Kabupaten/Kota yang bertugas dan bertanggung jawab di bidang bangunan gedung, yang sampai saat ini belum ada lembaga yang menangani pendaftaran tanah bangunan gedung.

Selanjutnya berdasarkan ketentuan Pasal 49 UU Rumah Susun, ketentuan lebih lanjut mengenai bentuk SHM Sarusun dan SKBG Sarusun dan tata cara penerbitannya akan diatur dengan peraturan pemerintah. Sampai saat ini peraturan pemerintah pelaksanaan UU Rumah Susun belum dibentuk baru disusun Rancangan Peraturan Pemerintah, apalagi peraturan pemerintah yang berkaitan dengan tata cara penerbitan SKBG Sarusun.

Selain kendala belum adanya peraturan pelaksanaan UU Rumah Susun, menurut Dodit Ardian Pancapana, belum ada instansi teknis yang bisa menangani pendaftaran Rumah Susun yang dibangun melalui pemanfaatan barang milik Negara/ daerah berupa tanah atau tanah wakaf. ${ }^{25}$ Instansi teknis yang bertanggung jawab di bidang bangunan gedung yang ditunjuk Undang-undang tidak tetap, seperti di Kota Bandung misalnya, Dinas Bangunan Gedung tidak permanen, saat ini Dinas Bangunan Gedung digabung dengan Dinas Perumahan dan Dinas Tata Ruang menjadi Dinas Tata Ruang dan Cipta Karya (Distarcip). Berbeda dengan Kantor Pertanahan, meskipun ada perubahan dari Kementrian Agraria menjadi Badan Pertanahan Nasional, Kantor Pertanahan tidak pernah berubah.

\section{SIMPULAN}

Kepemilikan satuan rumah susun saat ini sudah menerapkan asas pemisahan horizontal, namun Sertifikat Hak Milik Atas Satuan Rumah Susun yang menyatukan kepemilikan satuan rumah susun dengan tanah bersama menunjukkan masih dipengaruhi asas perlekatan. Dalam kepemilikan rumah susun melalui pemanfaatan barang milik negara/daerah berupa tanah dan pendayagunaan tanah wakaf dengan cara sewa dengan bukti kepemilikan berupa SKBG Sarusun menunjukan penerapan asas pemisahan horisontal secara konsisten. Berbagai upaya yang dilakukan pemerintah untuk memenuhi kebutuhan rumah bagi MBR belum sampai kepada pembangunan Rumah Susun diatas tanah asset Pemda dengan cara sewa, tetapi masih berkisar pada pembangunan rusunami dengan status HGB diatas Hak Pengelolaan sehingga masih belum terjangkau oleh MBR. Adapun yang menjadi kendalanya selain belum ada peraturan pelaksanaan UU Rumah Susun, juga belum ada instansi teknis yang dapat melaksanakan pendaftaran satuan rumah susun dengan bukti SKBG Sarusun. Untuk itu disarankan kepada Pemerintah Daerah

25 Wawancara dengan Dodit Ardian Pancapana, Kabid Perumahan Distarcip Kota Bandung, 11 Agustus 2014 untuk segera menindaklanjuti berbagai peraturan dengan mengeluarkan Perda yang berkaitan dengan pemenuhan Rumah Susun bagi MBR.

\section{DAFTAR PUSTAKA}

AP. Parlindungan, Komentar Atas Undang-undang Perumahan dan Permukiman dan Undang-undang Rumah Susun, Bandung : Mandar Maju, 2001

Betty Rubiati, "Kepemilikan Satuan Rumah Susun Yang Dibangun Melalui Pemanfaatan Barang Milik Negara/Daerah Berupa Tanah", Laporan Penelitian DIPA Fakultas Hukum Unpad Tahun 2013

Boedi Harsono, Hukum Agraria Indonesia, Sejarah Pembentukan Undang-undang Pokok Agraria, Isi dan Pelaksanaannya, Jilid 1, Jakarta : Penerbit Djambatan, 1994,

Menuju Penyempurnaan Hukum Tanah Nasional Dalam Hubungannya Dengan TAP MPR RI IX/MPR/2001, Jakarta : Penerbit Universitas Trisakti, 2003

Djuhaendah Hasan, Lembaga Jaminan Kebendaan Bagi Tanah Dan Benda Lain yang Melekat Pada Tanah Dalam Konsepsi Penerapan Asas Pemisahan Horisontal, Bandung : PT. Citra Aditya Bakti, 1996

Dirjen Cipta Karya, Dep. Pekerjaan Umum, “ UU Rusun Jamin Penyewa Hingga 60 Tahun", http:// ciptakarya.pu.go.id/v3/?act=vin\&nid $=1140, \quad 10$ Mei 2013

Dodit Ardian Pancapana, (Kabid Perumahan Distarcip Kota Bandung) "Pembangunan Peradaban, Membangun Tanpa Menggusur", disampaikan pada Focus Group Discussion Penerapan Asas Pemisahan Dalam Kepemilikan Tanah Dan Bangunan Satuan Rumah Susun Dalam Upaya Memenuhi Rumah Bagi MBR,

Imam Sudiyat, Hukum Adat Sketsa Asas, Yogjakarta : Liberty, 1981

Soerjono Soekanto,Penelitian Hukum, UI Press, Jakarta, 1990

Sumadi, Metode Penelitian, CV Rajawali, Jakarta, 1988

Tim Penyusun, Panduan Pendaftaran Hak Milik Atas Satuan Rumah Susun, Deputi Bidang Hak Tanah dan Pendaftaran Tanah, BPN RI, 2009

Yani Pujiwati, "Kedudukan Tanah Wakaf Dihubungkan Dengan Sertipikat Kepemilikan Bangunan Gedung Satuan Rumah Susun, LaporanPenelitian DIPA Fkultas Hukum Unpad 2013

Y. Fitriadi, “Kapan Lagi Ada Rusun Murah”, Harian Umum Pikiran Rakyat, 6 April 2013

"Menjamin Hak Bermukim MBR Di Perkotaan", Harian Umum Pikiran Rakyat, $24 \mathrm{Mei}$ 2014 